\title{
Satisfaction Level of Women Panchayat Members in Solapur District
}

\author{
*Dr. S.C.Adavitot
}

\begin{abstract}
An Attempt has been made to examine and assess the level of satisfaction of women panchayat members The study area is located in the southern part of Maharashtra and border place to Karnataka state. With the help of questionnaire a random sample survey of 1111 women panchayat members have been interviewed at their leisure time.. Their views were converted into numerical values. The factor wise level of satisfaction index has been computed. The study revealed that satisfaction index for change in social status was 7.17followed by support from husband 7.14, impact on family development 6.92 and so on. But women members were not happy about their involvement in Decision making process Generally, the women members were satisfied with existing conditions.
\end{abstract}

Keywords: Gender, Women Development, Women members, Satisfaction Index.

\section{Introduction :}

Gender geography covers various aspects of male-female relationship such as their attitude, economic, social and political status of women. The term 'status' denotes relative position of a person in social system. The term Gender refers to socially created distinctions between feminity and masculinity, while the term sex is used to refer the biological differences between men and women. It also study the implications of Gender in the study of geography are at least as important as implications of any other social or economic factor which transforms society and space. Therefore, here an attempt has been made to understand the status of women panchayat members at different space and place in the society.

\section{Objectives :}

The main objective of the present paper is to assess the satisfaction level of women panchayat members.

\section{Study Area:}

Solapur district entirely lies in the Bhima-Sina-Man basins, just before the Bhima River leaves Maharashtra State to enter into Karnataka State. Bounded by $17^{\circ} 10^{\prime}$ north and $18^{0} 32^{\prime}$ north latitudes and $74^{\circ} 42^{\prime}$ east and $76^{\circ} 15^{\prime}$ east longitudes, the district is fairly well-defined to its west as well as to its east by the inwardlooking scarps of Phaltan Range and the Osmanabad Plateau, respectively. The adjoining districts are Sangli to its south-west, Satara to its west, Pune to its north-west, Ahmadnagar to its north, Beed and Osmanabad to its east and the Bijapur district in Karnataka State to its south. Though of an irregular shape, the district is roughly squarish $200 \mathrm{~km}$ East-west and $150 \mathrm{~km}$. north-south.

\section{Data Base and Methodology :}

The study is entirely based on primary and secondary data. With the help of questionnaire a random sample survey was conducted and a total 1111 Women Panchayat Members were interviewed at their residence. Their views were then converted into numerical values, i.e. 08 to10 for Excellent, 06 to 08 for Good, 04to 06 for satisfactory and 00 to 04 for unsatisfactory. The factor wise level of satisfaction is calculated and tabulated. The indicator wise average values were further computed. The obtained values were used for calculating satisfaction index by following formula.

Where,

$$
\text { SIi }=\frac{\mathrm{M} \mathrm{i} \mathrm{N} \mathrm{i}}{\mathrm{N}}
$$

$\mathrm{SI} i=$ Satisfaction Index for ${ }^{\mathrm{i}} \mathrm{i}$, ${ }^{\text {th }}$ factor

$\mathrm{Mi}=$ Numerical values for particular level of satisfaction for the ${ }^{\mathrm{i}} \mathrm{i}$ ' ${ }^{\text {th }}$ factor

$\mathrm{Ni}=$ Number of respondents deriving the particular level of satisfaction for the ' $\mathrm{i}$ ' th factor

$\mathrm{N}=$ total number of respondents for that factors for all levels of satisfaction. 


\section{Level Of Satisfaction Of Women Members In Pri:}

Level of Satisfaction is a state of mind and there is universally accepted tool measure it. However, here an attempt has been made to assess the level of satisfaction by putting the question about level of satisfaction. The study reveals that only 230 Women Members were totally satisfied and more than 50 per cent were less satisfied because of the male dominated society. The taluka wise level of satisfaction is found similar in all talukas of the district. The taluka wise level of satisfaction is found similar in all talukas of the district.

Table No. 3.23 Solapur District: Distribution of level of satisfaction of women members in PRI

\begin{tabular}{|l|l|l|l|l|l|l|}
\hline \multirow{2}{*}{ Sr.No. } & Tahsils & \multicolumn{2}{|l|}{ Women members total satisfaction in Panchayatraj systems } & Total \\
\cline { 3 - 6 } & & $25 \%$ & $50 \%$ & $75 \%$ & $100 \%$ & \\
\hline 1 & Akkalkot & 18 & 34 & 19 & 21 & 92 \\
\hline 2 & Barshi & 21 & 56 & 28 & 23 & 128 \\
\hline 3 & Karmala & 26 & 38 & 24 & 19 & 107 \\
\hline 4 & Kurduwadi & 20 & 52 & 29 & 22 & 123 \\
\hline 5 & Malshiras & 31 & 44 & 38 & 30 & 143 \\
\hline 6 & Mangalwedha & 22 & 17 & 27 & 18 & 84 \\
\hline 7 & Mohol & 27 & 40 & 25 & 17 & 109 \\
\hline 8 & Pandharpur & 23 & 28 & 35 & 24 & 110 \\
\hline 9 & N-Solapur & 10 & 13 & 09 & 10 & 42 \\
\hline 10 & Sangola & 19 & 16 & 22 & 25 & 82 \\
\hline 11 & S-Solapur & 18 & 25 & 27 & 21 & 91 \\
\hline Total & & 235 & 363 & 283 & 230 & 1111 \\
\hline
\end{tabular}

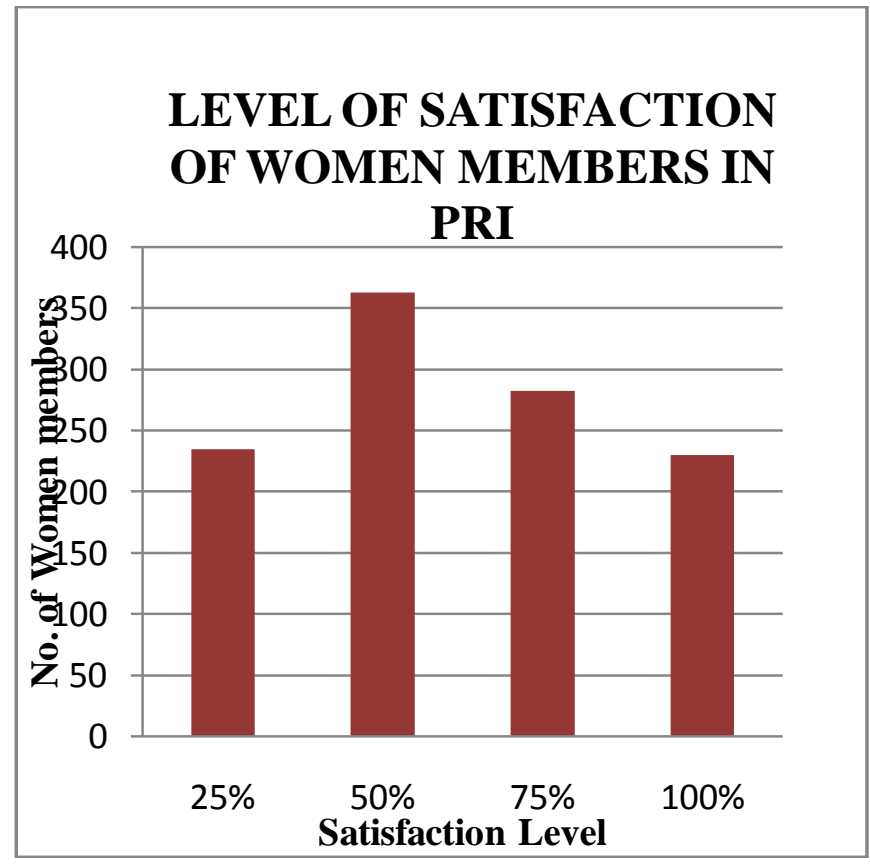

\section{VIEWS OF WOMEN MEMBERS REGARDING VARIOUS INDICATORS}

Different questions were asked to ascertain their views about various socio-economic and political indicators. The various views were noted in the rear 2010. These views were classified as excellent, good, satisfactory and unsatisfactory put in table no. 3.24.

\section{Change in Social Status:}

Government is always trying to change the status of women in the male dominated society. They are providing various facilities for women folk. Such as reservation in jobs, political field. Earlier 33 per cent reservation was kept in up to PRI level now it is 50 per cent. The present study reveals that maximum women members strongly supported that change is social status is taking place because of reservation in PRI. They are noted as excellent (56.25) near about 33.73 per cent were stated that they were overall satisfied. Only 9.90 per cent told that they were not satisfied because of attitude of male community. 


\section{Support from Husband and other family members:}

Gender geography covers various aspects of male ,female relationship. To enter into politics for women is not easy task in our rural life. The study observed that unless and until support from husband and other family members she could not enter into politics. It is also interesting to remark that 39.42 per cent women members informed us that their husband is sole responsible for their entry into politics. Only 5.94 per cent were not satisfied with the role of their family members.

\section{Impact on Family Development}

In questionnaire a question was asked about the impact on their family because of membership in PRI. 28.35 per cent noted as excellent,39.15 per cent were as good. Only .99 per cent were informed that the impact was not only because of PRI membership.

\section{Overall Impact of PRI Membership:}

Today we are living in the era of globalization. It was also accepted that women can replace man at each level of pri and other service sectors and all walks of life. Government of India is continuously promoting facilities such as free education, reservation in service and in politics. The present study also highlights the overall impact of PRI membership on their family and society. It is interesting to note that 47.97 per ent women member were of the view that their social status has been changed because of PRI membership. Only 9.36 per cent were not agree with this indicator. They were not satisfied because the overall impact is not only because of PRI membership there are other reasons.

Table No.3.24

Solapur District

Classification of views of Women Members about their socio-Economic and Political Impact

\begin{tabular}{|l|l|l|l|l|l|}
\hline $\begin{array}{l}\text { Sr. } \\
\text { No. }\end{array}$ & Indicators & Excellent & Good & Satisfied & Unsatisfied \\
\hline 1 & Change in social Status & 625 & 257 & 118 & 110 \\
& & $(56.25)$ & $(23.13)$ & $(10.62)$ & $(9.90)$ \\
\hline 2 & Support From Husband & 438 & 502 & 105 & 66 \\
& & $(39.42)$ & $(45.18)$ & $(9.45)$ & $(5.94)$ \\
\hline 3 & Respect from other Male PRI & 76 & 115 & 728 & 92 \\
& members & $6.84)($ & $(10.35)$ & $(65.52)$ & $(8.25)$ \\
\hline 4 & Involvement in Decision Process & 80 & 210 & 710 & 111 \\
& & $(7.20)$ & $(18.90)$ & $(63.90)$ & $(9.99)$ \\
\hline 5 & Support from Govt. Officers & 102 & 308 & 511 & 190 \\
& & $(9.18)$ & $(27.72)$ & $(45.99)$ & $(17.10)$ \\
\hline 6 & Awareness about Gram Saba \& & 58 & 202 & 408 & 433 \\
& Development & $(5.22)$ & $(18.18)$ & $(36.72)$ & $(38.97)$ \\
\hline 7 & Impact on family Development & 315 & 435 & 350 & 011 \\
& & $(28.35)$ & $(39.15)$ & $(31.50)$ & $(0.99)$ \\
\hline 8 & Overall impact of PRI Membership & 67 & 533 & 407 & 104 \\
& & $(6.03)$ & $(47.97)$ & $(36.63)$ & $(9.36)$ \\
\hline & Average & 156.75 & 320.25 & 480.50 & 139.62 \\
\hline & Per cent & 14.00 & 29.00 & 44.00 & 13.00 \\
\hline
\end{tabular}

Source: Based on field work,2010

\section{Awareness about Gram Saba and its role in Development:}

The concept of GS has been introduces with the view to solve the problems of people with greater coordination between the administration and people and to encourage participation of people. The GS have been allotted powers so that the benefits of government schemes should reach the common people. 38.97 per cent PRI members were expressed that they were not satisfied. At the same time 36.72 per cent women PRI members just reacted about this indicator as it was good. Only 5.22 per cent women members were agreed that there is always positive correlation between GS and Rural Development. They were educated WM in PRI and they agreed that various development issues were discussed on the floor of the Gram-Saba.

\section{Respect from other Male PRI Members:}

The present study highlighted the gender relation in space context. 65.52 per cent of women members were just satisfied about this relation but while discussing with women PRI members it is observed that still men are not cooperating with them. Only 6.84 per cent were noted that the relationship between them is excellent, it is because of their family members involved directly in PRI system.8.25cent were totally not satisfied with gender relation. 


\section{Support from government Officers:}

The PRI system is attached with government officers starting from GP to ZP. Along with Sarpanch a Gramsevak , Block Development Officer at Panchayat Samiitee level and ZP level CEO is attached. The study reveals that only 9.18 per cent were noted as excellent and it is only because of their counterpart is playing a vital role in PRIas ex. Member, Sarpanch.45.99 per cent told that they were satisfied and 17.10 per cent were not satisfies with the behavior and support from government officers.

\section{Involvement in Decision Making:}

There are many schemes which are routed through gram panchayats. The study also collected the information about the involvement of women members in decision making process about development issues. Unfortunately. The study reveals that 63.40 per cent of women were just satisfied as they were saying that they involved in decision process, 7.20 per cent replied that it was excellent it happens only to educated PRI members. 9.90 per cent were noted that they not satisfied because their views were not considered so far as they belongs to reserve category.

After analyzing the views of all level Women PRI members it is found that on an average 44 per cent of Women PRI members were satisfied about their role in overall development of villages. Followed by 29 per cent were noted it was good, only 14.00 per cent told that it was really excellent for them and still 13.00 per cent were not satisfied with the overall functioning system of PRI.

\section{Indicator wise Level Of Satisfaction}

Levels of satisfaction is a state of mind and there is universally accepted tool to measure it. However, here an attempt has been made to assess the level of satisfaction by adopting certain satisfaction methods. Table 3.25 reveals indicator wise distribution of women PRI member.

Indicator wise average values are calculated for the identification of levels of satisfaction of Women PRI members in the study region. They were asked to assign points out of ten (Maximum)

For the particular level of satisfaction they derived from each indicator. To ensure uniformity a forced distribution of pints were adopted for convenience, like 08 to 10 as excellent, 06 to 08 , as good, 04 to 06 as satisfactory and below 04 as unsatisfactory. The average values for different levels of satisfaction for the different indicators are shown in the table 3.24

Table No. 3.25 Solapur District Indicator-wise Average Values of Satisfaction

\begin{tabular}{|l|l|l|l|l|l|}
\hline $\begin{array}{l}\text { Sr. } \\
\text { No. }\end{array}$ & Indicators & Excellent & Good & Satisfied & Unsatisfie \\
\hline 1 & Change in social Status & 9.12 & 9.28 & 8.26 & 2.03 \\
\hline 2 & Support From Husband from other Male PRI & 7.30 & 9.20 & 8.18 & 2.00 \\
\hline 3 & $\begin{array}{l}\text { Respect from } \\
\text { members }\end{array}$ & 7.86 & 6.90 & 1.30 \\
\hline 4 & Involvement in Decision Process & 6.01 & 6.10 & 5.52 & 1.10 \\
\hline 5 & Support from Govt. Officers Saba \& & 6.95 & 7.10 & 5.70 & 1.20 \\
\hline 6 & $\begin{array}{l}\text { Awareness about Gram Sag } \\
\text { Development }\end{array}$ & 8.02 & 7.00 & 1.60 \\
\hline 7 & Impact on family Development & 8.90 & 9.01 & 7.89 & 1.98 \\
\hline 8 & Overall impact of PRI Membership & 8.80 & 8.95 & 7.60 & 1.90 \\
\hline
\end{tabular}

Source: Based on Field Work (2010)

These average values are used to calculate satisfaction indices. The ranks are given to these indicators which depict the priority of the indicators.

\section{Satisfaction Index:}

The satisfaction index for the year 2010 worked out in Table no. 3.26 which is as follows. Due to reservation the positive social change was taking place therefore it ranks first.(7.17), followed by support from husband(7.14),Third rank 6.92 for impact on family development, Overall impact of PRI membership(6.81) etc,. and last rank was given to involvement in Decision making(4.68). To conclude, it is observed that the women PRI members were satisfied.

Table No. 3.26 Indicator-wise Satisfaction Index with Rank(2010)

\begin{tabular}{|l|l|l|l|}
\hline Sr. No. & Indicators & Satisfaction Index & Rank \\
\hline 1 & Change in social Status & 7.17 & I \\
\hline 2 & Support From Husband & 7.14 & II \\
\hline 3 & Impact on family Development & 6.92 & III \\
\hline 4 & Overall impact of PRI Membership & 6.81 & IV \\
\hline
\end{tabular}




\begin{tabular}{|l|l|l|l|}
\hline 5 & $\begin{array}{l}\text { Awareness about Gram Saba \& } \\
\text { Development }\end{array}$ & 6.15 & V \\
\hline 6 & $\begin{array}{l}\text { Respect from other Male PRI } \\
\text { members }\end{array}$ & 5.84 & VI \\
\hline 7 & Support from Govt. Officers & 5.13 & VII \\
\hline 8 & Involvement in Decision Process & 4.68 & VIII \\
\hline
\end{tabular}

Source: Based on Field Work (2010)

\section{Conclusion:}

The satisfaction index revealed that Due to reservation the positive social change was taken place therefore it ranked first, followed by support from husband, third rank for impact on family development, Overall impact of PRI membership(6.81) etc,. and last rank was given to involvement in Decision making(4.68). To conclude, it is observed that the women PRI members were satisfied. The present research work is skewed either in the direction of better socio-economic and political conditions or inferior socio-economic and political conditions of women members of PRI.

\section{Acknowledgement:}

I am very much thankful to ICSSR, NEW DELHI for sanctioning and providing MRP and financial support to complete the project. This research paper is out come of this project

\section{References:}

\begin{tabular}{|l|l|c|l|}
\hline \multicolumn{1}{|c|}{1.} & G. Palanithurai & 2000 & $\begin{array}{l}\text { Grass root Democracy in Indian Society, Concept publishing } \\
\text { company }\end{array}$ \\
\hline 2. & G. Palanithurai & 2004 & $\begin{array}{l}\text { Dynamics of New PRI in India edited Vol.IV Empowering } \\
\text { women, Concept publishing company }\end{array}$ \\
\hline 3 & Hazel D'lima & 1983 & $\begin{array}{l}\text { Women in Local Government, Concept publishing company, } \\
\text { New Delhi }\end{array}$ \\
\hline 4 & $\begin{array}{l}\text { B.S. Baviskar \& George } \\
\text { Mathew }\end{array}$ & 2008 & $\begin{array}{l}\text { Inclusion and Exclusion in Local Governess Sage Publications, } \\
\text { New Delhi }\end{array}$ \\
\hline 5 & Arun, Rashmi & 1996 & $\begin{array}{l}\text { Role of Women in Panchayati Raj", The Administrator 12,April- } \\
\text { June }\end{array}$ \\
\hline 6 & Socio-Economic Review \& District Statistical Abstract of Solapur District (2011) \\
\hline 7 & The gazetteer of Solapur District \\
\hline 8 & Statistical Department, Govt. of Maharashtra, Solapur \\
\hline
\end{tabular}

